\title{
A New Combination and Change in Rank in Polycarpon (Caryophyllaceae), Endemic to California, U.S.A., and Mexico
}

\author{
Duilio Iamonico \\ Laboratory of Phytogeography and Applied Geobotany, Section Environment and Landscape, \\ Department DPTA, Sapienza University of Rome, via Flaminia 72, I-00196 Rome, Italy. \\ d.iamonico@yahoo.it
}

Abstract. The name Polycarpon depressum Nutt. (Caryophyllaceae) is here investigated and lectotypified. According to a recent molecular investigation and based on the morphology and ecology of the taxon, the new combination and change in rank for $P$. tetraphyllum (L.) L. subsp. depressum (Nutt.) Iamonico are proposed for these plants endemic to California, U.S.A., and northern Mexico. A description of the subspecies is provided as is a comparison with the similar taxa $P$. tetraphyllum subsp. tetraphyllum, P. tetraphyllum subsp. alsinifolium (Biv.) Ball, and P. tetraphyllum subsp. diphyllum (Cav.) O. Bolòs \& Font Quer.

Key words: Baja California, California, Caryophyllaceae, Mexico, Polycarpon, United States.

Polycarpon L., as traditionally circumscribed, includes about 16 species distributed in warm and temperate regions of the world (Fraga \& Rosselló, 2011). Kool et al. (2007) showed the polyphyly of this genus using DNA sequence data. Three different phylogenetic lineages with high support values were highlighted: (1) the aggregate $P$. coquimbense Gereau \& Martic./P. suffruticosum Griseb. (from South America), (2) P. prostratum (Forssk.) Asch. \& Schweinf. (widespread, tropical), and (3) the $P$. tetraphyllum aggregate (main diversity in the Mediterranean region). According to Kool et al. (2007), $P$. coquimbense, $P$. suffruticosum, and $P$. prostratum should be excluded from Polycarpon. The remaining accessions representing the $P$. tetraphyllum clade were a polyploid complex that can be treated as a single species, P. tetraphyllum (L.) L. These results led Iamonico (2013, 2015a, 2015b) and Iamonico and Domina (2015) to recognize a single species for the Mediterranean and European flora and to propose six combinations: $P$. tetraphyllum subsp. catalunicum (O. Bolòs \& Vigo) Iamonico \& Domina (Iamonico \& Domina, 2015), P. tetraphyllum subsp. colomense (Porta) Iamonico \& Domina (Iamonico \& Domina, 2015), P. tetraphyllum subsp. dunense (P. Fraga \& Rosselló) Iamonico, P. tetraphyllum subsp. herniarioides (Ball.) Iamonico \& Domina (Iamonico \&
Domina, 2015), P. tetraphyllum subsp. polycarpoides (Biv.) Iamonico, and P. tetraphyllum subsp. sauvagei (Mathez) Iamonico.

Polycarpon depressum Nutt. (from California, U.S.A., and northern Mexico) belongs to the $P$. tetraphyllum aggregate (Kool et al., 2007), but it was not discussed by Iamonico and Domina (2015). We here present a nomenclatural study of the name $P$. depressum and provide information about its morphology, ecology, and distribution in western North America. Polycarpon depressum is also compared with related subspecies belonging to the $P$. tetraphyllum aggregate.

\section{Materials and Methods}

This paper is based on analysis of the relevant literature and examination of historic collections by Thomas Nuttall (1786-1859). Original material was found in the following herbaria: BM, DUKE, E, F, FI, GH, K, LIV, MO, NY, OXF, and PH. Further specimens were searched at CAT, CICY, HFLA, K, MA, PAL, RO, and W (acronyms according to Thiers, 2011).

\section{Results And Discussion}

TYPIFICATION

The protologue of Polycarpon depressum (Torrey \& Gray, 1838: 174) consists of a short description in English and the habitat and locality details, "On bare sand-hills, near St. Diego, California"; no synonyms were cited. The authors indicated " $P$. depressum (Nutt. ! mss.)" and credit Nuttall for the description and collection information (cf. Art. 46.1 Ex. 4, McNeill et al., 2012). According to Stafleu and Cowan (Pennell, 1936, quoted in Stafleu \& Cowan, 1981: 781), the Nuttall collection is preserved at BM, but "...in 1818, he kept few or no specimens for himself, presenting a complete series of his plants to the Academy of Natural Science (PH) so that there repose his early types." Specimens useful for the 
typification purpose were found at $\mathrm{BM}, \mathrm{GH}, \mathrm{K}$, and PH.

Specimens of Polycarpon depressum at BM (barcode [bc] 000583671) and GH (bc 00037828) bear plants collected by Nuttall in San Diego that are certainly part of the original material for the name $P$. depressum. Nuttall's plant preserved at K (bc K000723279) is at the top right of a sheet, together with five other collections of $P$. depressum (bc K000723274-78). The plant at the top left (bc K000723274), although collected by Nuttall, included the annotation "Catalina Isl," which refers to Santa Catalina, an island located in Los Angeles County and not San Diego as reported in the protologue. As a consequence, this exsiccatum cannot be considered part of the original material. Concerning the other plants (bc K000723275-78), they are not part of Nuttall's original material because: (1) they were not collected in San Diego County (in other areas of California or in Mexico); (2) they are dated after 1838, the year of Nuttall's publication (dates are 1876 [bc K000723275], 1880 [bc K000723277], June 1883 [bc K000723276], and 1876 [bc K000723278]); and (3) they were not collected by Nuttall (collectors were C. C. Parry \& J. G. Lemmon [bc K000723275], G. R. Vasey [bc K000723277], C. R. Orcutt [bc K000723276], and C. C. Parry \& J. G. Lemmon [bc K000723278]) (see Selected Specimens).

The collections of Polycarpon depressum at PH (bc 01078359 and 00020592 ) were annotated by Nuttall, although the second sheet was associated with the script "Calolina" (sic, Santa Catalina Island in Los Angeles County), a locality not cited in the protologue. So the specimen PH00020592 is not part of the original material for the name $P$. depressum. The collection PH01078359 does indeed refer to a plant collected in San Diego (original annotation, "St. Diego U. Calif.") and is part of the original material.

All of the Nuttall exsiccatae that were traced (bc BM 000583671, GH 00037828, K 000723279, and PH 01078359) show features that correspond to the 1838 diagnosis of Polycarpon depressum. However, the date of collection does not occur on any label, so if we strictly apply the rules of the IUCN (McNeill et al., 2012), we might not consider these specimens as part of the original material (the plants could have been collected before 1838). Despite this, according to Freire-Fierro and Landale (2011: 109), Nuttall certainly used the PH Herbarium as his home institution during the earlier stages of his career in the United States. Consequently, Nuttall specimens at $\mathrm{PH}$ comprise part of his original material, and they should be even treated as holotypes. However, Nuttall usually studied more than one specimen per species, and this was the case with $P$. depressum. According to Article 9.5 of the IUCN (McNeill et al., 2012), the specimens traced at $\mathrm{BM}, \mathrm{GH}, \mathrm{K}$, and $\mathrm{PH}$ can be considered syntypes, and therefore a lectotype may be designated among them (Art. 9.2). I here designate the specimen at $\mathrm{PH}$ as lectotype of the name $P$. depressum, while the remaining sheets would be isolectotypes.

\section{TAXONOMIC DISCUSSION}

Torrey and Gray (1838: 173-174) reported two species of Polycarpon for North America: $P$. tetraphyllum as introduced ("about Charleston, S. Carolina") and $P$. depressum attributed to Nuttall, to his description and collection. On the basis of the descriptions provided, $P$. depressum differed in having the leaves only opposite, the sepals not mucronate, and the stamens three to five (whereas $P$. tetraphyllum has "leaves quaternate and opposite...sepals mucronate...stamens 3"); moreover, the authors reported "Leaves 2-3 lines long. Flowers very small," highlighting the smaller size of the plants of $P$. depressum (Torrey \& Gray, 1838: 173174). Current treatment of Polycarpon in the Flora of North America, North of Mexico (Thieret \& Rabeler, 2005) listed $P$. depressum as having smaller sepals and stipules, sepals not or slightly keeled, and leaves only opposite. The Linnaean name P. tetraphyllum (s. str., cf. Kool et al., 2007) referred to a taxon native to Europe, Africa, the Mediterranean region, and southwestern Asia (Chater \& Akeroyd, 1993) and introduced in Australia (APNI, 2012) and North America (Howell, 1941; Thieret \& Rabeler, 2005). On the basis of our observations, $P$. depressum is morphologically distinct from $P$. tetraphyllum s. str. by its smaller size (in all parts of the plant), the leaves only opposite (never whorled), and the sepals flat to scarcely keeled. Among the other annual taxa belonging to the $P$. tetraphyllum clade (sensu Kool et al., 2007), two appear more similar to $P$. depressum than P. tetraphyllum s. str.: P. tetraphyllum subsp. diphyllum (Cav.) O. Bolòs \& Font Quer and $P$. tetraphyllum subsp. alsinifolium (Biv.) Ball. The taxon $P$. depressum differs morphologically from these two subspecies in size (e.g., habit, sepals, petals); in the arrangement, shape, and thickness of leaves; and in the seed surface (e.g., Amich \& Pedrol, 1990; Iamonico, 2014) (cf. Table 1).

Concerning its taxonomic identity, Polycarpon depressum is included in the $P$. tetraphyllum clade sensu Kool et al. (2007), and the North American species is also affiliated with Eurasian taxa based on molecular evidence. Populations of $P$. depressum 


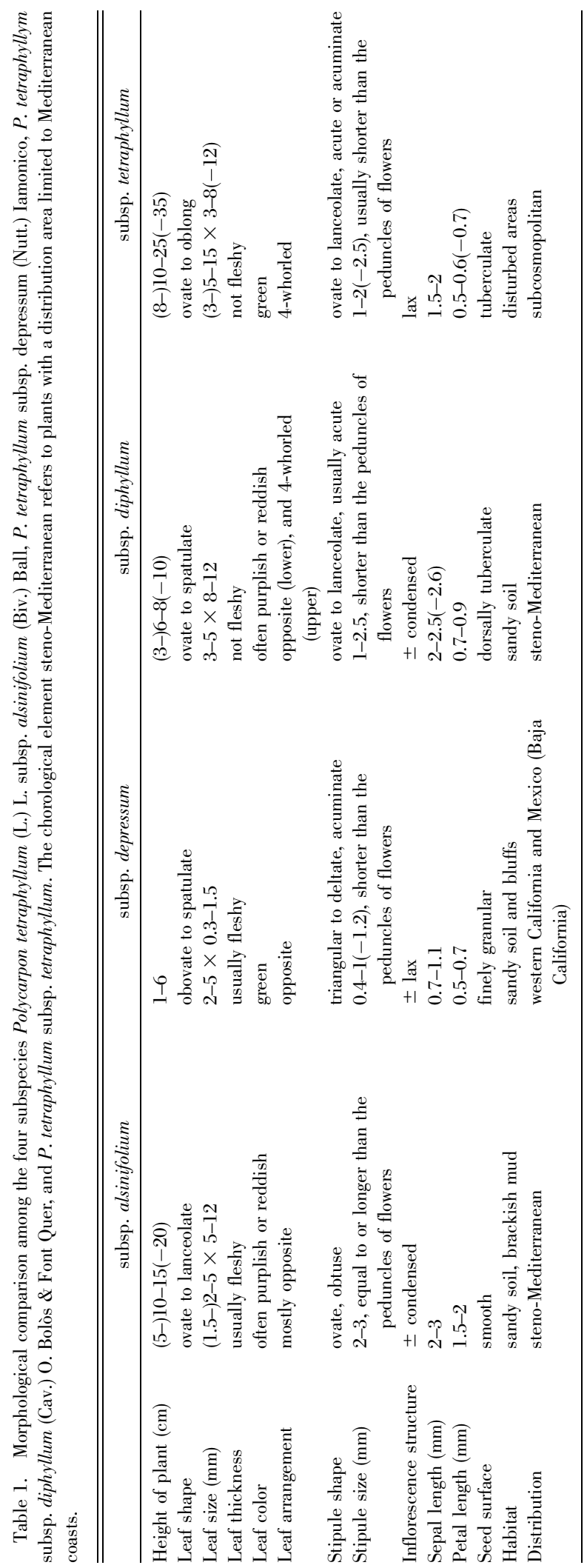




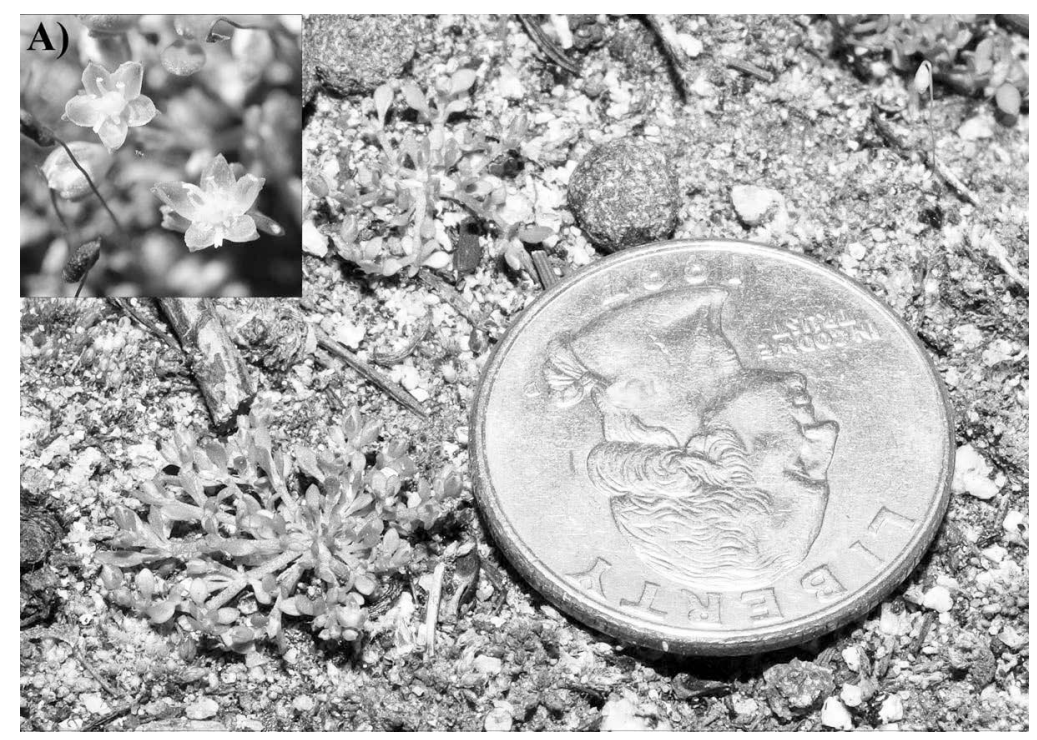

Figure 1. Plants of Polycarpon tetraphyllum (L.) L. subsp. depressum (Nutt.) Iamonico from Santa Margarita river trail, San Diego, California. -A. Detail of flowers. Photos by K. Morse (12 Mar. 2011).

mostly grow in coastal habitats in gravelly or sandy soil or bluffs, while $P$. tetraphyllum s. str. colonizes disturbed areas. Polycarpon tetraphyllum subsp. diphyllum and P. tetraphyllum subsp. alsinifolium can be found in habitats similar to those of $P$. depressum. Notably, the distribution area of $P$. depressum is completely disjunct, with $P$. depressum being endemic to coastal sites in southern California and Baja California in Mexico.

On the basis of available evidence (molecular data, morphological features, ecology, and distribution patterns), I conclude that subspecies is a better rank for the American taxon Polycarpon depressum and therefore propose the new combination P. tetraphyllum subsp. depressum (Nutt.) Iamonico. Its description is emended and expanded.

Polycarpon tetraphyllum (L.) L. subsp. depressum (Nutt.) Iamonico, comb. et stat. nov. Basionym: Polycarpon depressum Nutt. in Torr. \& A. Gray, Fl. N. Amer. 1: 174. 1838. TYPE: U.S.A. California: "St. Diego, U. Calif.," s.d. [fl.], T. Nuttall s.n. [ex Herb. Nutt.] (lectotype, designated here, PH [ bc 01078359]; at sheet lower right; image at <http://ph.ansp.org/ get_image.php?barcode $=00020592 \&$ mode $=$ full>; isolectotypes, BM [bc BM000583671]; image at $<$ http://plants.jstor.org/specimen/ bm000583671?history=tue>), K [bc K000723279]; image at <http://www.kew.org/herbcatimg/ 324680.jpg>, GH [bc GH00037828; image at $<$ http://plants.jstor.org/stable/10.5555/al. ap.specimen.gh00037828>. Figure 1.

Annual herb, 1-6 cm tall; stems prostrate-diffuse, green to reddish green, branched. Leaves opposite, not whorled, with blades obovate to spatulate, $2-5 \times$ $0.3-1.5 \mathrm{~mm}$, cuneate at base, acute or obtuse at apex, entire at margins, green, petiolate, with the petiole 1$4 \mathrm{~mm}$; stipules 2 , narrowly triangular to deltate, 0.4 $\mathrm{l}(-1.2) \mathrm{mm}$, acuminate, silvery scarious, persistent. Inflorescence as dichasial cymes, terminal and axillary, densely flowered, glabrous, lateral branches each subtended by a lanceolate bract. Flower bisexual; sepals usually 5 , unequal, lanceolate to ovate, $0.7-1.1 \mathrm{~mm}$, usually green, flat to scarcely keeled, with margins whitish green, membranous; petals usually 5 , linear to elliptic, $0.5-0.7 \mathrm{~mm}$, shorter than sepals, acute to truncate at apex, whitish; stamens 3 to 5 , free, with filaments appressed to ovary; anthers ca. $0.2 \mathrm{~mm}$, yellow; pistil one, $0.3-0.5$ $\mathrm{mm}$. Fruit a loculicidal capsule, ovoid, ca. $1.7 \times 1.1-$ $1.2 \mathrm{~mm}$, dehiscent by 3 twisting valves, 10- to 16 seeded; seeds D-shaped to triangular, $0.4-0.5 \times$ ca. $0.4 \mathrm{~mm}$, black, finely granular.

Habitat, distribution, and phenology. Polycarpon tetraphyllum subsp. depressum can be considered an endemic taxon for North America. In the United States, it is known only in California (from the counties of Alameda, Los Angeles, Marin, Monterey, Orange, Riverside, San Benito, San Bernardino, San Diego, San Luis Obispo, San Mateo, Santa Barbara, Santa Cruz, and Ventura), and in Mexico, only in 
Baja California (Thieret \& Rabeler, 2005; Calflora, 2014; CCH, 2014; TheNAT, 2014). These plants have been collected from gravelly or sandy soil, from coastal bluffs and chaparral, and at elevations of 10$560 \mathrm{~m}$. Flowering has been observed from April to June.

Selected specimens. MEXICO. Baja California: June 1883, C. R. Orcutt s.n. (K [bc K000723276]); San Telmo, 16 Apr. 1886, C. R. Orcutt s.n. (MO-445323); near Vallecito, Lower California, 22 May 1886, C. R. Orcutt s.n. (MO445322); 1 km SE of Peñasco la Lobera, R. Moran 26599 (MO-445324); Sonoran Desert, Vizcaino region, Arroyo San Andrés, B. A. Prigge, D. S. Verity \& D. C. Michener 4738 (MO-445321). U.S.A. California: San Bernardino, 1880, G. R. Vasey 697 (K [bc K000723277]); 1876, C. C. Parry \& J. C. Lemmon s.n. (K [bc K000723278]); "Southern California," 1876, C. C. Parry \& J. C. Lemmon 24 (K [bc K000723275]); Alameda Co., near North Hall, 24 Sep. 1906, W. A. Setchell s.n. (JEPS [bc JEPS51377]); Alameda Co., Albany, B. Crampton 2015 (UC [bc UC35221]); Monterey, Pajaro Hills, H. P. Chandler 426 (UCR [bc UCR8362]); Ft. Ord Eucalyptus Rd., Mud Hen Lake near burn, Northern Monterey Co., 25 May 1998, V. Yadon s.n. (PGM [bc PGM4260]); Los Angeles, "Calolina," s.d., T. Nuttall s.n. (PH [bc PH00029592]); "Catalina Isl," s.d, T. Nuttall s.n. (K [bc K000723274]); Santa Monica Mtns., Stone Canyon, 13 Apr. 1935, M. Hilend s.n. (LA [bc LA94346]); foothills of San Gabriel Mtns., betw. Chantry Trail \& La Vina Sanitarium, ridge $\mathrm{S}$ side of $\mathrm{W}$ ravine, L. C. Wheleer 8049 (RSA [bc RSA604600]); Orange Co., roadside, s.d., J. R. Bruff s.n. (RSA [bc RSA696556]); Aliso Creek, Aliso Creek Bike Trail, 3 km ENE Moulton Peak, Aliso Viejo, F. M. Roberts 3376 (IRVC [bc IRVC25471]); Riverside Co., Wilder's Canyon, Jurupa Mtns., Apr. 1905, C. M. Wilder s.n. (POM [bc POM48845]); NW Palomar Mtns., Agua Tibia Mtns., Cleveland National Forest, Agua Tibia Wilderness Area, N face of Agua Tibia Mtn., Dorland Mtn. area, D. L. Banks \& S. D. Boyd 0082 (RSA [bc RSA585646]); San Diego Co., La Mesa, June 1927, B. Goessman s.n. (SD [bc SD1606]); jct. Sweetwater Rd. \& Jamul Rd., D. F. Howe 1079 (SD [bc SD13387]); burned hillside near Pala, 30 Mar. 1940, F. F. Gander 7975 (SD [bc SD26574]); Oakcrest Park, Encinitas, 17 Apr. 1978, T. Oberbauer s.n. (SD [bc SD99557]); San Diego Co., Cleveland National Forest, along Nate Harrison Grade ca. 1.5 mi. N of Hwy. 76, N side of rd., R. Lauri 407 (SDSU [bc SDSU15998]); San Luis Obispo Co., Baywood Park, R. F. Hoover 6926 (OBI [bc OBI19442]); Black Lake sign at crossing of Calif. Hwy. 1, D. J. Keil \& E. A. Wise 18559 (OBI [bc OBI4100]); Nipomo Dunes, Big Coreopsis Hill S of Oso Flaco Lake, D. J. Keil et al. 21501 (OBI [bc OBI53177]); Santa Barbara Co., near Santa Barbara, 1888, T. S. Brandegee s.n. (UCR [bc UCR174991]); Santa Ynez Mtns., Old San Marcos Pass Rd., NE of Goleta, C. F. Smith 4384 (UCR [be UCR54668]); Santa Cruz Co., Sunset Beach State Park, 22 Apr. 1995, R. Morgan s.n. (UCSC [bc UCSC6135]); Ventura Co., N of E Casitas Pass hwy. (Hwy. 150), ca. 0.5 mi. W of Casitas Lake, 27 Apr. 1962, H. M. Pollard s.n. (SBBG [bc SBBG40954]); Santa Monica Mtns., Deer Canyon, 16 Mar. 1974, M. H. Grayum \& D. R. Perry s.n. (SFV [bc SFV6134]).

Selected specimens examined for other subspecies of Polycarpon tetraphyllum. Polycarpon tetraphyllum (L.) L. subsp. alsinifolium (Biv.) Ball. ALGERIA. El Taref: à la Calle, s.d., M. C. Durieu s.n. (PAL-57867). ITALY.
Calabria: Reggio, s.d., Citarda s.n. (PAL-57866). Sicily: Palermo a Mondello, s.d., A. Todaro s.n. (PAL-47364); Palermo, Madonie, rupi di Quacella, G. Bartolo et al. 1613 (PAL); Siracusa, Noto, Vendicari, a $\mathrm{S}$ di Calamosche, $R$. Galesi 2057 (CAT); Caltanissetta, Niscemi, Piano Stravolata, R. Galesi 7649 (CAT); Enna, Monte Navone, Piazza Armerina, R. Galesi 7574 (CAT).

Polycarpon tetraphyllum (L.) L. subsp. diphyllum (Cav.) O. Bolòs \& Font Quer. ITALY. Lazio: Isola di Ponza, tra Bivio e Le Forna, B. Anzalone 12822 (RO). Sicily: Catania, Castel di Iudica, Monte Turcisi, R. Galesi 621 (CAT); Caltanissetta, Gela, Piano Stella, Passo delle Pantanelle, $S$. Sciandrello 866 (CAT). SPAIN. Valencia: Devesa de l'Albufera, en pastizales de Anthyllido-Malcomion lacerae Rivas Goday, J. B. Peris \& G. Stubing 68 (RO).

Polycarpon tetraphyllum (L.) L. subsp. tetraphyllum. ALGERIA. Algiers: Alger, M. Brichi s.n. (RO). AUSTRALIA. New South Wales: Cumberland, near Sidney, s.d., s. coll. s.n. (RO). AUSTRIA. Wien: Wien, 2. Bezirk, Böcklinstraße 23 und Josef-Gall-Gasse, 4 July 2010, $R$. Diran s.n. (W); 16. Bezirk, raum Konstantingasse-Odoakergasse-Wögingergasse, 16 Sep. 2011, W. Adler s.n. (W). GREECE. Central Greece: Athens, 10 June 1893, $T$. Heldreich s.n. (RO). ITALY. Friuli-Venezia Giulia: ager Tergestinus, Tergeste... in ruderatis, Aug. 1917, C. Marchesetti s.n. (RO). Lazio: Tenuta di Castel Porziano, Tor Paterno, B. Anzalone 12809 (RO). Piedmont: Torino, Parco del Valentino, E. Ferrari 596 (RO). Sicily: Caltanissetta, ferrata a San Cataldo, May 1900, I. Di Giovanni s.n. (RO); Palermo alla Pizzuta, June 1900, I. Di Giovanni s.n. (RO). Tuscany: Grosseto, agro di Roccastrada, loc. Pian di Muro verso Sticciano, 27 Aug. 2010, F. Selvi s.n. (PAL-89164). PORTUGal. Centro: Coimbra, Cumiada, A. Moller 331 (RO).

Acknowledgments. Thanks are due to the directors and curators of all cited herbaria for their support during our visits and loan of specimens or photographs. I am also grateful to K. Morse (San Diego, California) for the permission to reproduce his photos of Polycarpon depressum.

\section{Literature Cited}

Amich, F. \& J. Pedrol. 1990. Polycarpon. Pp. 61-167 in S. Castroviejo, M. Laínz, G. López González, P. Montserrat, F. Muñoz Garmendia, J. Paiva \& L. Villar (editors), Flora Iberica, Vol. 2. Real Jardín Botánico, CSIC, Madrid.

APNI. 2012. Australian Plant Name Index. <http://www. anbg.gov.au/cgi-bin/apni $>$, accessed 14 February 2014. Calflora. 2014. The Calflora Database. <http://www. calflora.org/>, accessed 15 February 2014.

Chater, A. O. \& J. R. Akeroyd. 1993. Polycarpon. Pp. 184185 in T. G. Tutin, N. A. Burges, A. O. Chater, J. R. Edmondson, V. H. Heywood, D. M. Moore, D. H. Valentine, S. M. Walters \& D. A. Webb (editors), Flora Europaea, 2nd ed., Vol. 1. Cambridge University Press, Cambridge.

Consortium of California Herbaria (CCH). 2014. Data provided by the participants of the Consortium of California Herbaria. <http://ucjeps.berkeley.edu/ consortium/ $>$, accessed 15 February 2014.

Fraga, P. \& J. A. Rosselló. 2011. Polycarpon dunense (Caryophyllaceae), a new psammophilous species from Minorca (Balearic Islands). Flora Montiber. 47: 29-35. 
Freire-Fierro, A. \& A. Landale. 2011. Lectotypification of Thomas Nuttall's names applied to North American Polygala (Polygalaceae). J. Bot. Res. Inst. Texas 5: 109124.

Howell, J. T. 1941. Notes on Polycarpon. Leafl. W. Bot. 3: 80.

Iamonico, D. 2013. Notula 1997. Polycarpon tetraphyllum L. subsp. polycarpoides (Biv.) Iamonico stat. nov. (Caryophyllaceae). Notulae nomenclaturali alla Checklist della flora italiana: 15. Inform. Bot. Ital. 45(1): 105.

Iamonico, D. 2014. Polycarpon in S. Pignatti (editor), Flora d'Italia, Vol. 1. Edagricole, Bologna (in press).

Iamonico, D. 2015a. A new nomenclatural change in Polycarpon (Caryophyllaceae): P. tetraphyllum subsp. sauvagei comb. \& stat. nov., an endemic taxon from Morocco. Phytotaxa 197(3): 225-226, <http://dx.doi.org/ 10.11646/phytotaxa.197.3.7>, accessed 15 June 2015.

Iamonico, D. 2015b. Polycarpon tetraphyllum subsp. dunense (P. Fraga \& Rosseló) Iamonico. Pp. 120-121 in E. Raab-Straube von \& T. Raus (editors), Euro+MedChecklist Notulae 4. Willdenowia 45(1).

Iamonico, D. \& G. Domina. 2015. Nomenclatural notes on the Polycarpon tetraphyllum aggregate (Caryophyllaceae). Pl. Biosystems 148. doi: 10.1080/11263504.2015. 1057260 .

IUCN. 2010. The IUCN Red List of Threatened Species, Version 2010.4. <http://www.iucnredlist.org >, accessed 15 February 2014.
Kool, A., A. Bengtson \& M. Thulin. 2007. Polyphyly of Polycarpon (Caryophyllaceae) inferred from DNA sequence data. Taxon 56(3): 775-782.

McNeill, J., F. R. Barrie, W. R. Buck, V. Demoulin, W. Greuter, D. L. Hawksworth, P. S. Herendeen, S. Knapp, K. Marhold, J. Prado, W. F. Prud'homme van Reine, G. F. Smith, J. H. Wiersema \& N. J. Turland (editors). 2012. International Code of Nomenclature for Algae, Fungi, and Plants (Melbourne Code). Regnum Veg. 154.

Pennell, F. W. 1936. Travels and scientific collections of Thomas Nuttall. Bartonia 18: 1-51.

Stafleu, F. A. \& R. S. Cowan. 1981. Taxonomic Literature, 2nd ed., Vol. 3. Bohn, Scheltema \& Holkema, Utrecht.

TheNAT. 2014. The Flora of Baja California. <http:// bajaflora.org/index.aspx $>$, accessed 15 February 2014.

Thieret, J. W. \& R. K. Rabeler. 2005. Polycarpon. Pp. 9-48 in C. C. Freeman, K. Gandhi, R. K. Hartman, R. W. Kiger, N. R. Morin, R. K. Rabeler \& J. L. Strother (editors), Flora of North America North of Mexico, Magnoliophyta: Caryophyllidae, Pt. 2, Vol. 5. Oxford University Press, New York.

Thiers, B. 2011. Index Herbariorum: A global directory of public herbaria and associated staff. New York Botanical Garden's Virtual Herbarium. < http://sweetgum.nybg.org/ ih/ $>$, accessed 15 February 2014

Torrey, J. \& A. Gray 1838. A Flora of North America, Vol. 1. Wilet \& Putnam, and Bossange \& Co., New York, London, and Paris. 